A. Klimczuk, Welfare State, [in:] B. Turner, P. Kivisto, W. Outhwaite, C. Kyung-Sup, C. Epstein, J.M. Ryan (eds.), The Wiley-Blackwell Encyclopedia of Social Theory, Wiley-Blackwell, London 2017, pp. 1-5, http://dx.doi.org/10.1002/9781118430873.est0406.

\title{
Welfare State
}

\section{ANDRZEJ KLIMCZUK}

\section{Warsaw School of Economics, Poland}

The welfare state refers to a concept of a state that focuses on ensuring that a broad range of social rights is provided for all citizens by acting on the social mechanisms and consequences of the market economy. In such a state government plays a vital role in balancing social inequalities by providing or subsidizing social benefits and services. This activity is called social policy. Individual countries are characterized by different welfare state models, goals, values, and groups of beneficiaries. Such a state usually supports a recovery from a difficult situation experienced by all or part of the population that is not able to meet their basic needs themselves.

The welfare state is usually described by features such as guaranteeing a minimum income for families and individuals, regardless of the market value of their property. It focuses on providing security in case of social risks that would otherwise lead to individual and family crises and the provision of social services to maintain a certain level of life for all citizens. Such services include assisting nonworking populations in capitalist societies. In a broader sense, the welfare state offers a basis of social, economic, and political equality, peace, democracy, human rights, equal opportunities for education, public safety, environmental protection, and participation of citizens in governance.

The social policy is planned, coordinated, funded and/or implemented by the state. Usually, it aims to improve human welfare, to meet basic human needs, and focus on resolving social problems that have been publicly recognized as important. The social policy focuses on the management of social risks in the subjective dimension (such as social problems of women, workers, peasants, families, labor unions, ethnic minorities, and people with disabilities); in the life-course dimension (problems of children, adults, older people); and in the objective dimension (such as unemployment, poverty, health, education, homelessness, migration, alcoholism, prostitution). The scope and forms of support, services, and expenditures offered by institutions of the welfare state vary depending on the country due to different cultural and socioeconomic traditions and possibilities. Usually, the areas of the social policy include social security, pensions, social assistance/care, unemployment insurance or employment policy, environmental policy, health policy, housing policy, child protection, social inclusion, crime, and criminal justice, demographic policy, family policy, migration policy, education policy, 
A. Klimczuk, Welfare State, [in:] B. Turner, P. Kivisto, W. Outhwaite, C. Kyung-Sup, C. Epstein, J.M. Ryan (eds.), The Wiley-Blackwell Encyclopedia of Social Theory, Wiley-Blackwell, London 2017, pp. 1-5, http://dx.doi.org/10.1002/9781118430873.est0406.

and cultural policy.

Charity for the poor has been known since ancient times. However, until the period of the Industrial Revolution, it was regulated by custom and without the participation of the state. Exceptions to this are regulations such as the English Statute of Laborers of 1351 and Poor Laws codified in 1587-1598. The authorship of the concept of social policy in its modern meaning is attributed to the French philosopher and social reformer Charles Fourier, who lived at the turn of the eighteenth and nineteenth centuries. Spreading capitalist relations of production have led to the emergence of the so-called social issues, particularly the labor rights issues. The social policy aimed at mitigating the most severe symptoms of such issues or radical removal of their sources. The turning point was the introduction in 1833 of state factory inspectors in England to monitor compliance with the new laws shortening the working day of adults, adolescents, and children.

Otto von Bismarck and William Beveridge were the pioneers of state social policy. They introduced solutions that can be divided into two pathways of development of the welfare state (Bonoli 1997). Bismarck, as the first Chancellor of Germany, created a conservative regime of social security, in which people received the help that depended almost entirely on their contributions. In the $1880 \mathrm{~s}$, he introduced old-age pensions, medical care, and accident insurance. These solutions have been disseminated to all European welfare states. The primary objective of this system was to reduce the strength of the socialist opposition, to decrease the outflow of migrants to the United States, and to improve the loyalty of the society to the state.

The second path of development of the welfare state was defined in 1942 by the report of William Beveridge, who was a British economist and political adviser. The purpose of the report was to organize existing forms of assistance and identify solutions to eliminate the five problems aggravated by World War II: disease, ignorance, poverty, unemployment, and deprivation. Beveridge proposed to solve them through a government intervention that could provide an adequate income, healthcare, education, housing, and employment. This approach was more concerned about meeting the needs than the methods of funding. This model was implemented through a series of Acts of Parliament aimed at the relative cheapness of universal benefits.

Beveridge's ideas contributed to the rise of minimal/liberal welfare regimes (in the AngloSaxon countries) and more generous social-democratic regimes (in the Nordic countries). The liberal regime is also represented by the United States where the welfare state emerged in the 1930s (Trattner 2007). Franklin D. Roosevelt's New Deal during the Great Depression was 
A. Klimczuk, Welfare State, [in:] B. Turner, P. Kivisto, W. Outhwaite, C. Kyung-Sup, C. Epstein, J.M. Ryan (eds.), The Wiley-Blackwell Encyclopedia of Social Theory, Wiley-Blackwell, London 2017, pp. 1-5, http://dx.doi.org/10.1002/9781118430873.est0406.

aimed at the reduction of unemployment. The New Deal included the introduction of retirement pensions, partially free health service, unemployment insurance, welfare for the handicapped and children in single-parent families, minimum wages, public works, a guarantee of labor unions' freedom, banned child labor, and limited the working week.

In the years 1880-1914, in most European countries, the first social insurances were introduced, and adult men gained electoral rights. However, the extension of political rights initially did not include the poor who received assistance from public institutions. An estimated welfare expenditure of European countries during this period did not exceed 3 percent of GDP. However, from the mid-1970s, welfare expenditure had increased to about 20 percent of GDP. The basis of the modern welfare state is the doctrine of British economist John Maynard Keynes. In his book, The General Theory of Employment, Interest, and Money (1936/2007), he promoted state intervention aimed at supporting full employment. This model served as an economic standard in developed countries during the Great Depression, World War II, and the postwar economic expansion (1945-1973). After the oil shock and stagflation of the 1970s, it lost some influence. More attention was paid to the phenomenon of welfare retrenchment (cuts of various cost and policy areas, increasing qualification conditions to make benefits less universal). Reforms focused on changing passive into active social policies have also been emphasized (the promotion or enforcement of participation) (Starke 2006; van Berkel and Moller 2002). Keynesian economics resurfaced with the global financial crisis in 2007-2008.

According to Thomas Humphrey Marshall (1950), the welfare state emerged when governments decided to take responsibility for providing social/welfare rights as a part of the development of citizenship (the twentieth century). These rights arose after the development of a certain level of civil rights (the eighteenth century) and political rights (the nineteenth century). The development of rights corresponds to changes in the public systems of resource allocation. They shift from the principles of reciprocity to the market allocation and the redistribution of benefits for the needy by the welfare state.

Gosta Esping-Andersen (1990) suggests that the welfare state was established through the implementation of socialist aspirations as a supplement to the capitalist economy. This "welfare capitalism" is, therefore, an institution created under the pressure of the working class and labor union movement, which in some countries was stronger than the power of the bourgeoisie.

Among the other historical factors in the development of the welfare state and social policy were fears of the upper classes from the pathological behavior of the poverty struck urban neighborhoods. Significant was also the fear of entrepreneurs from the effects of spontaneous 
A. Klimczuk, Welfare State, [in:] B. Turner, P. Kivisto, W. Outhwaite, C. Kyung-Sup, C. Epstein, J.M. Ryan (eds.), The Wiley-Blackwell Encyclopedia of Social Theory, Wiley-Blackwell, London 2017, pp. 1-5, http://dx.doi.org/10.1002/9781118430873.est0406.

and unorganized workers' rebellions manifested in the destruction of machinery. There was also, among entrepreneurs, an increased understanding of the need to ensure the reproduction of the labor force and to improve its quality (education, investment in the human capital).

Economic arguments for the welfare state include, among others, the recognition that the redistribution of income in favor of the poorest is the most efficient way to increase demand and eliminate the cyclical crises of overproduction. Moreover, it was noted that public sector demand for social services stimulates the general economic situation. These observations are associated with the understanding that, through Paul A. Samuelson's theory of public goods, market allocation fails in relation to the indivisible goods. Thus, in some areas, the public sector shows greater rationality than the market.

Contemporary development of the institutions of the welfare state is stimulated by factors such as striving for competitive balance between industries in different countries; competition between political regimes; and fear of adverse effects of South-North migration. Thus, welfare states in the Global South are created by the diffusion of social insurance solutions from the Global North by strategies of social development and support of the professional staff of international agencies such as the World Bank (Midgley and Livermore 2009).

Comparisons of welfare states in the period after World War II were based on the idea of their possible convergence with the economic development in other countries (Clarke 2008). The welfare state was seen as a recipe for a "third way" - between capitalism and communism. Describing the diversity of the welfare state models was possible by broadening the analysis of quantitative criteria by including qualitative criteria such as conditions of access to social benefits and services, their quality, and involvement of different welfare entities.

One of the first influential typologies of welfare states was proposed by Richard Titmuss (1979). He distinguished three models. The first, the residual welfare, focuses on meeting the needs of individuals through private markets and family. The social policy acts here, as ad hoc solutions, only when these mechanisms fail, for example, as in the United States. The second, the handmaiden model, includes social programs added to a market economy. It assumes the priority of merit and productivity in the process of meeting the needs, for example, Germany and the former Soviet Union. Third, the institutional redistributive model is considered as an integral institution in the framework of a society that guarantees universal access to social benefits and services, for example, in the United Kingdom.

Esping-Andersen in 1990 modified the classification created by Titmuss through the introduction of the decommodification index associated with the impact of social benefits and 
A. Klimczuk, Welfare State, [in:] B. Turner, P. Kivisto, W. Outhwaite, C. Kyung-Sup, C. Epstein, J.M. Ryan (eds.), The Wiley-Blackwell Encyclopedia of Social Theory, Wiley-Blackwell, London 2017, pp. 1-5, http://dx.doi.org/10.1002/9781118430873.est0406.

social services on social stratification. He proposed a typology of welfare regimes linked to dominant political movements of the twentieth century in Western countries. The first group of states is described as a social-democratic regime - a high degree of decommodification, high wage replacement by social benefits, full employment policy, and the strong position of labor unions, for example, the Nordic countries. The second group covers a Christian democracy/conservatism regime - the state supports the family; social security depends on the position of individuals in the labor market. Benefits are based on insurance contributions while the state recognizes the priority of local communities in social interventions, for example, Austria, France, Germany, and Italy. The third group refers to a liberal regime - individualism and responsibility of the individuals to their social security, low decommodification, and social benefits; benefits are based on income and a small role of labor unions, for example, the United States, Canada, and Australia.

There are attempts to expand Esping Andersen's typology to include the models of social policy in other regions of the world (Wood and Gough 2006). Thus, there are also countries that are rebuilding their welfare state, according to the liberal model of social policy. These actions are associated with building a free market economy under the influence of international financial institutions, for example, Latin America, countries of the former Soviet Union. The second group, called the productivist welfare regime, refers to East Asian countries (for example, Indonesia, Philippines, Vietnam). Here states pay more attention to increasing economic productivity than to social policy. The third model, called informal security, characterizes South Asia (for example, Bangladesh, Nepal, Pakistan) and covers inefficient postcolonial state bureaucracy that leads to a situation in which people are seeking social security through family and local communities. The fourth group, insecurity regimes, includes the countries of sub-Saharan Africa, which are characterized by uncoordinated and unstable solutions proposed by local leaders, warlords, corrupt officials, and international aid organizations.

Broadening the concept of the welfare state sometimes includes the use of the term "the welfare society" both as a descriptive and normative category. It puts emphasis on the increasing role citizens play in the provision of social services. Another avenue through which to modify the welfare state is to analyze and promote cooperation and the division of tasks between the various sectors of public life, defined as the mixed economy of welfare or the welfare mix/pluralism. These concepts refer to a provision of welfare by state/public entities, commercial entities, the nongovernmental sector, entities of the social economy (such as social 
A. Klimczuk, Welfare State, [in:] B. Turner, P. Kivisto, W. Outhwaite, C. Kyung-Sup, C. Epstein, J.M. Ryan (eds.), The Wiley-Blackwell Encyclopedia of Social Theory, Wiley-Blackwell, London 2017, pp. 1-5, http://dx.doi.org/10.1002/9781118430873.est0406.

enterprises and cooperatives), and the informal sector (the civil society) (Powell 2007; Midgley and Livermore 2009).

At the beginning of the twenty-first century, some scholars and international organizations promoted a shift from the term welfare to well-being, a closely related alternative (OECD 2011). These terms are often used interchangeably. However, welfare refers to goals, aims, and inputs of policy (for example, the level of public spending), while well-being refers to outputs and outcomes (for example, what has happened).

SEE ALSO: Capitalism; Disability and Impairment; Inequality; Keynes, John Maynard; Poverty, Poverty Level; State; Welfare Economics

\section{REFERENCES}

Bonoli, Giuliano. 1997. Classifying Welfare States: A Two-Dimension Approach. Journal of Social Policy, 26(3): 351-372.

Clarke, John. 2008. Reconstructing Nation, State and Welfare: The Transformation of Welfare States. In Welfare State Transformations: Comparative Perspectives, edited by Martin Seeleib-Kaiser, 197-209. New York: Palgrave Macmillan.

Esping-Andersen, Gosta. 1990. The Three Worlds of Welfare Capitalism. Princeton, NJ: Princeton University Press.

Keynes, John M. 1936/2007. The General Theory of Employment, Interest, and Money. New York: Palgrave Macmillan.

Marshall, Thomas H. 1950. Citizenship and Social Class, and Other Essays. Cambridge: Cambridge University Press.

Midgley, James and Livermore, Michelle. eds. 2009. The Handbook of Social Policy, 2nd edn. Thousand Oaks, CA: SAGE.

OECD. 2011. How's Life? Measuring Well-being. Paris: OECD.

Powell, Martin A., ed. 2007. Understanding the Mixed Economy of Welfare. Bristol, UK: Policy Press.

Starke, Peter. 2006. The Politics of Welfare State Retrenchment: A Literature Review. Social Policy \& Administration, 40(1): 104-120.

Titmuss, Richard M. 1979. Social Policy: An Introduction. London: George Allen \& Unwin. Trattner, Walter I. 2007. From Poor Law to Welfare State: A History of Social Welfare in America, 6th edn. New York: Free Press. 
A. Klimczuk, Welfare State, [in:] B. Turner, P. Kivisto, W. Outhwaite, C. Kyung-Sup, C. Epstein, J.M. Ryan (eds.), The Wiley-Blackwell Encyclopedia of Social Theory, Wiley-Blackwell, London 2017, pp. 1-5, http://dx.doi.org/10.1002/9781118430873.est0406.

van Berkel, Rik and Moller, Iver H., eds. 2002. Active Social Policies in the EU: Inclusion Through Participation? Bristol, UK: Policy Press.

Wood, Geof and Gough, Ian. 2006. A Comparative Welfare Regime Approach to Global Social Policy. World Development, 34(10): 1696-1712.

\section{FURTHER READING}

Cousins, Mel. 2005. European Welfare States: Comparative Perspectives. Thousand Oaks, CA: SAGE.

Haggard, Stephan and Kaufman, Robert R. 2008. Development, Democracy, and Welfare States: Latin America, East Asia, and Eastern Europe. Princeton, NJ: Princeton University Press.

Powell, Jason and Hendricks, Jon, eds. 2009. The Welfare State in Post-industrial Society: A Global Perspective. Dordrecht: Springer.

Yeates, Nicola, ed. 2008. Understanding Global Social Policy. Bristol, UK: Policy Press. 